\title{
SIFAT DAN KARAKTERISTIK NILAI EIGEN SISI KANAN ATAS MATRIKS QUATERNION
}

\author{
Tri Susilawati, Amir Kamal Amir, Nurdin \\ Jurusan Matematika, Fakultas MIPA, Universitas Hasanuddin
}

\begin{abstract}
ABSTRAK
Ada beberapa sifat nilai eigen di matriks riil yang berlaku juga di matriks quaternion namun dengan syarat tertentu. Penelitian ini bertujuan merumuskan sifat dan karakteristik nilai eigen sisi kanan atas matriks quaternion. Penelitian ini dilakukan dengan cara, pertama mengumpulkan referensi-referensi yang berkaitan dengan nilai eigen sisi kanan atas matriks quaternion, kedua melakukan kajian kepustakaan terhadap referensi yang diperoleh, ketiga merumuskan sifat dan karakteristik nilai eigen sisi kanan atas matriks quaternion. Penelitian menghasilkan rumusan sifat dan karakteristik nilai eigen sisi kanan atas matriks quaternion. Kata kunci : Nilai eigen, nilai eigen sisi kanan, matriks quaternion.
\end{abstract}

\section{PENDAHULUAN}

Perkembangan teknologi dan informasi saat ini tak bisa dipungkiri juga mempengaruhi ilmu pengetahuan lainnya. Tak terkecuali dalam ilmu matematika. Matematika yang pada dasarnya dibagi menjadi dua jenis kajian yaitu terapan dan murni ikut berkembang seiring perkembangan penelitian-penelitian yang lebih dahulu.

Matematika murni yang dibagi menjadi beberapa kajian antaranya aljabar pun sangat mengalami perkembangan. Aljabar abstrak merupakan suatu cabang ilmu matematika yang cirri khasnya sarat dengan aksioma-aksioma, dimana sering dianggap sebagai subyek yang ideal untuk menyelesaikan suatu pembuktian (Sutojo dkk., 2010). Manipulasi-manipilasi aljabar digunakan sebagai salah satu cara membuktikan lemma-lemma dalam penelitian ini. Aljabar yang bersifat abstrak cenderung lebih mudah dikembangkan dibandingkan kajian lainnya. (Isnarto, 2008). Tak terkecuali dengan materi nilai eigen. Nilai eigen pada matriks riil cenderung tak banyak mengalami perkembangan disbanding matriks quaternion. Bilangan quaternion yang tidak bersifat komutatif lebih memungkinkan dikembangkan terutama kajian secara aljabar (Hamilton, 2000).
Teori dasar tentang matriks quaternion diciptakan oleh Sir William Rowan Hamilton (1805-1865), seorang pakar aljabar, astronomi dan fisika dari Irlandia yang secara formal diperkenalkan pada tahun 1843, dan merupakan generalisasi dari bilangan kompleks 4D (Shoemake, 2007). Bilangan quaternion telah diaplikasikan secara luas, diantaranya pada komputer grafik, komputer vision, robotik, teori kontrol, sinyal prosesing, fisika, bioinformatika, dinamika molekular dan mekanik (Pei dkk., 2001).

Jika nilai eigen matriks atas bilangan riil tidak terbagi lagi menjadi sisi kiri dan kanan, lain halnya dengan nilai eigen matriks atas bilangan quaternion. Hal ini disebabkan karena sifat perkalian pada bilangan quaternion yang tidak komutatif. Penelitian ini didasarkan pada sebuah definisi yang telah dibuat oleh peneliti sebelumnya (Flaut, 2002).

Fuzen (1997) sudah menjelaskan beberapa sifat nilai eigen sisi kanan atas maatriks quaternion yang hanya berlaku untuk matrik quaternion saja. Hasil penelitian tersebut belum secara rinci membahas mengenai nilai eigen sisi kanan atas matriks quaternion. Penelitian Zhang tersebut merupakan penyempurnaan dari peneliti sebelumnya (Brenner, 1951).

Berdasarkan beberapa referensi, sifatsifat nilai eigen matriks atas bilangan riil 
sudah sangat banyak ditemui. Berbeda halnya dengan nilai eigen sisi kanan atas matriks quaternion. Ada beberapa sifatsifat nilai eigen matriks atas bilangan riil yang berlaku pula untuk nilai eigen sisi kanan atas matriks quaternion. Sifat - sifat yang tidak berlaku tersebut akan berlaku dengan syarat dan karakteristik tertentu. Penggunaan matriks yang representative bisa memudahkan dalam merumuskan karakteristik nilai eigen sisi kanan atas matriks quaternion (Tian, 2000). Sifat dasar matriks quaternion merujuk pada sifat matriks yang telah diteliti sebelumnya (Morais dkk., 2012).

Syarat dan karakteristik khusus yang berlaku untuk nilai eigen sisi kanan atas matriks quaternion tersebut yang menjadi topik penelitian ini. Penelitian ini bertujuan untuk merumuskan sifat dan karakteristik nilai eigen sisi kanan atas matriks quaternion

\section{METODE PENELITIAN}

\section{Lokasi dan Rancangan Penelitian}

Penelitian ini bertempat di Jurusan

\section{Matematika FMIPA Universitas}

Hasanuddin. Rancangan penelitian ini berbentuk penelitian kuantiitatif dengan melakukan studi kepustakaan, dengan mengumpulkan dan mengkaji materimateri yang berkaitan dengan sifat-sifat aljabar Quaternion, matriks quaternion, nilai eigen atas matriks quaternion, serta sifat dan karakteristik nilai eigen sisi kanan atas matriks quaternion.

\section{Analisis Data}

Penelitian dilakukan dengan berdasarkan sifat nilai eigen atas bilangan Real kemudian sifat tersebut dirumuskun juga dalam matriks quaternion sehingga menghasilkan sifat dan karakteristik nilai eigen sisi kanan atas matriks quaternion.

\section{HASIL PENELITIAN}

Sifat dan karakteristik nilai eigen sisi kanan atas matriks quaternion yang diperoleh adalah sebagai berikut.

Lemma 4.1. Jika $\lambda$ adalah nilai eigen sisi kanan dari A yang bersesuaian dengan vektor eigen $x$ maka, $\lambda^{n}$

Bukti : adalah nilai eigen dari $A^{n}$.

Akan ditunjukkan bahwa $A^{n} x=x \lambda^{n}$ benar untuk $n=1$

$$
\begin{aligned}
& A^{1} x=x \lambda^{1} \\
& A x=x \lambda
\end{aligned}
$$

Asumsikan bahwa $A^{n} x=x \lambda^{n}$ benar untuk $n=k$ yaitu $A^{k} x=x \lambda^{k}$ selanjutnya akan dibuktikan benar juga untuk $n=k+1$

$$
\begin{aligned}
A^{k+1} x= & A^{k} A x \\
& =A^{k}(A x) \\
& =A^{k}(x \lambda) \\
& =\left(A^{k} x\right) \lambda \\
& =\left(x \lambda^{k}\right) \lambda \\
& =x \lambda^{k+1}
\end{aligned}
$$

Lemma 4.2. Jika $x$ adalah vektor eigen dari A dan $\lambda$ adalah nilai eigen sisi kanan, maka $x k$ adalah vektor eigen dari A yang bersesuaian dengan nilai eigen $\lambda$ asalkan $\lambda k=k \lambda$ untuk sebarang skalar quaternion $\mathrm{k}$.

Bukti: $A x=x \lambda$

$$
\begin{aligned}
& A x k=x \lambda k \\
& A(x k)=(x k) \lambda
\end{aligned}
$$

Lemma 4.3. Jika $\lambda$ adalah nilai eigen sisi kanan dari A, maka $\lambda k$ adalah nilai eigen dari $A k$ asalkan $x k=k x$ untuk sebarang skalar quaternion $\mathrm{k}$.

Bukti: $A x=x \lambda$

$$
A x k=x \lambda k
$$

$x(\lambda k)$

Karena $\quad x k=k x$ maka $(A k) x=$

Lemma 4.4. Jika $x$ dan $y$ adalah vektor eigen dari A yang bersesuaian dengan nilai eigen sisi kanan $\lambda$, maka $(x+y)$ adalah vektor eigen dari A yang bersesuaian dengan nilai eigen $\lambda$.

$$
\begin{aligned}
\text { Bukti: } & A x=x \lambda \text { dan } A y=y \lambda \\
& A x+A y=x \lambda+y \lambda \\
& A(x+y)=(x+y) \lambda
\end{aligned}
$$

\section{PEMBAHASAN}

Penelitian ini menghasilkan rumusan sifat-sifat dn karakteristik nilai eigen sisi kanan atas matriks quaternion 
Penelitian ini melibatkan proses manipulasi aljabar yang cukup sederhana. Manipulasi aljabar ini penting untuk membuktikan salah satu lemma yang tidak berlaku di matriks quaternion tetapi berlaku di matriks riil..

Hasil penelitian ini menunjukkan bahwa sifat nilai eigen pada bilangan Real berlaku pula pada nilai eigen sisi kanan atas matriks quaternion hanya saja ada syarat dan karakterustik yang harus dipenuhi.

\section{KESIMPULAN DAN SARAN}

Berdasarkan hasil dan pembahasan dapat disimpulkan bahwa ada beberapa sifat nilai eigen pada matriks riil yang berlaku untuk nilai eigen sisi kanan atas matriks quaternion. Penelitian ini masih bisa dikembangkan lagi antara lain merumuskan sifat dan karakteistik nilai eigen sisi kiri atas matriks quaternion. Sehingga dapat menjadi peluang penelitian ke depan.

\section{DAFTAR PUSTAKA}

Brenner J. L. (1951). Matrices of Quaternions. Pasific J. Vol. 1, No. 3. Bad Month

Fuzhen Zhang. (1997). Quaternions and Matrices of Quaternions Linear Algebra and Its Applications

Flaut Cristina. (2002). Eigenvalues And Eigenvectors for the Quaternion
Matrices Of Degree Two. An. St. Univ. Ovidius Constanta, Vol. 10(2), hal 39-44

Hamilton W.R. (2000). On Quaternion or On A New System of Imaginaries in Algebra. Massachussets :D.C. Heath and Company.

Isnarto. (2008). Struktur aljabar. Yogyakarta: UGM Press.

Morais Joao Pedro dkk. (2012). Real quaternionic Calculus Handbook. Birkhause.

Pei S.C dkk. (2001). Efficient Implementation of Quaternion Fourier Transform, convolution and Correlation by 2-D Complex FFT : IEEE Transactions on signal Processing, Vol. 49, No. 11, hal: 2783-2797

Sutojo T. N., Bowo N. dkk. (2010). Teori dan Aplikasi Aljabar Linier \& Matriks. Yogyakarta: Penerbit Andi.

Shoemake K. (2007). Quaternions. Departement of Computer and Information science. University of Pennysylvania. Philadelpia. PA 19104.

Tian Y. (2000). Matrix representations of octonions and their applications : Advances in

App. Clifford Algebras 10, No.1, 6190, 